\title{
FIRST REPORT OF CANINE MYIASIS WITH SHEEP NASAL BOT FLY, Oestrus ovis, IN SLOVENIA
}

\author{
Aleksandra Vergles Rataj ${ }^{\star}$, Petra Bandelj, Vladimira Erjavec, Darja Pavlin \\ ${ }^{1}$ Veterinary Faculty, University of Ljubljana, cesta V Mestni log 47, SI-1115 Ljubljana, Slovenia \\ *Corresponding author, Email: aleksandra.verglesrataj@vf.uni-lj.si
}

\begin{abstract}
First larval stage (L1) of Oestrus ovis was recovered by flushing of the nasal cavity during rhinoscopy in an urban living dog. The dog was taken to the Small animal clinic after an acute onset of sneezing and bilateral nasal discharge. In Europe, there are sporadic reports of nasal myiasis in dogs caused by sheep bot flies, and the overall prevalence of $O$. ovis is high in Mediterranean countries. Because of its habitat expansion due to climate change, it should be considered as a differential diagnosis when an animal patient presents with signs of rhinitis in areas bordering the Mediterranean climate. This is the first report of a dog infested by sheep nasal bot fly in Slovenia.
\end{abstract}

Key words: Oestrus ovis; sheep bot fly; nasal myiasis; dog; climate change

\section{Introduction}

The sheep ectoparasite, Oestrus ovis L. (Linnaeus 1758) is commonly known as nasal bot fly of sheep, goats, and other wild ruminants (1), although infestations of dogs $(2,3,4,5,6)$, humans (7) and a cat (8) have also been documented. It has a worldwide distribution, with a preference to warmer climate, where adult flies can be active year-round (9). In Europe, it has a high prevalence in Mediterranean regions, where seroprevalence in sheep can reach from $43.3-91 \%(10,11,12)$. In Slovenia, the prevalence was assessed at $40 \%$ (13).

Received:22April 2021

Accepted for publication: 27 July 2021
The presence of the parasite in the population can be detrimental to the infested animals $(12,14)$, as the larval stages of the $O$. ovis invade sinu-nasal passages (1). If the infestation is severe, the animal may suffer further complication of the respiratory system, such as chronic pneumonia unresponsive to antimicrobial treatment (15). Reports of dogs with $O$. ovis infestation are rare but show that dogs can harbor all stages of larvae, including mature larval instar (5). Clinical signs in dogs are mild in the early stage of infestation (4) but can become severe if symptoms go unnoticed, even leading to euthanasia of the animal (3). With some exceptions (3), most cases are associated with the dog or cat living on a sheep farm or in an area of high sheep density $(4,5,8)$. 


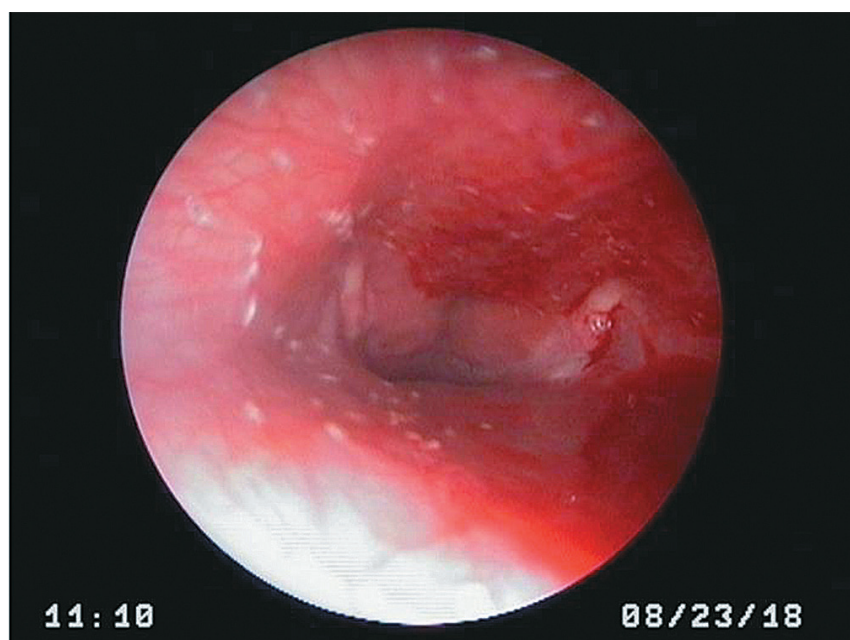

Figure 1: Multiple Oestrus ovis L1 in the nasopharynx of the dog during retroflex nasopharyngoscopy

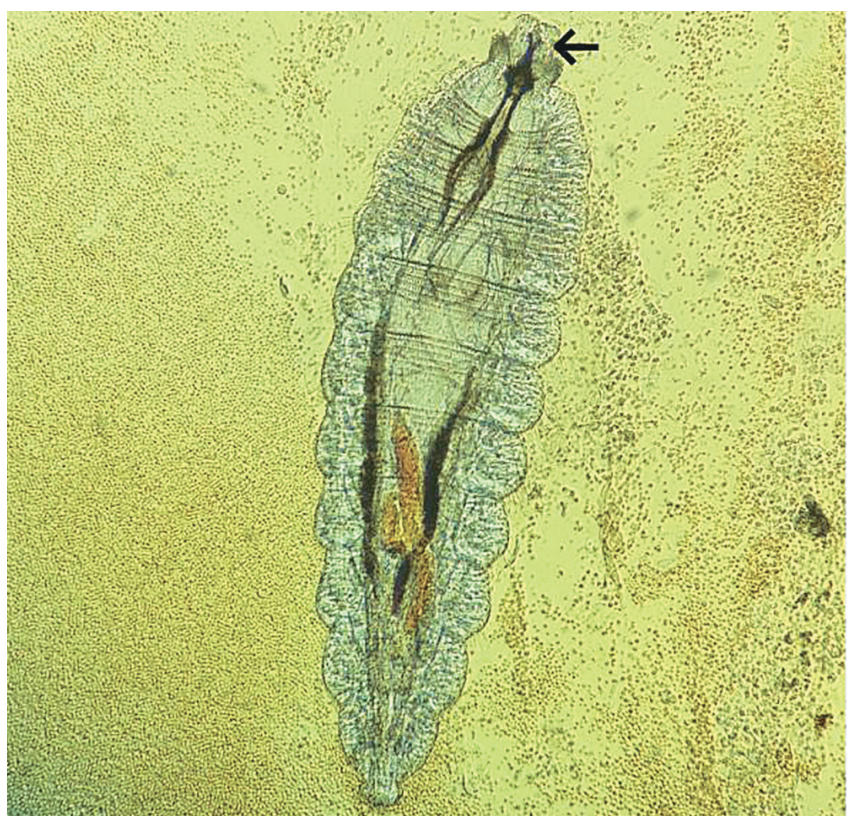

Figure 2: Oestrus ovis L1 segmented body with two dark brown oral hooks (arrow) on the first body segment

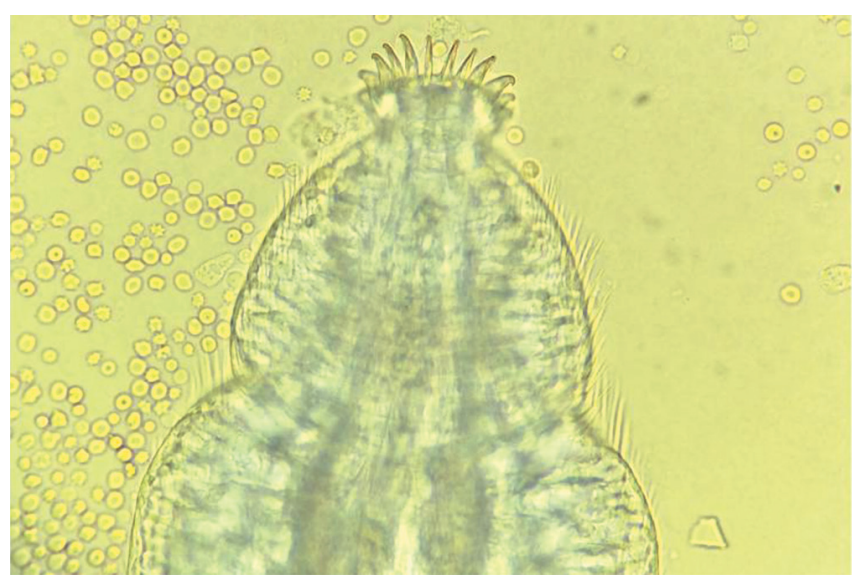

Figure 3: Oestrus ovis L1 caudal spines on the last body segment
The aim of this report is to describe the first case of sheep nasal bot fly infestation in a dog in Slovenia with no history of being in contact with sheep or sheep associated areas.

\section{Case presentation}

In August 2018, a spayed 4-year-old West Highland White Terrier female dog living in the city of Ljubljana (latitude $46^{\circ} 03^{\prime} 03^{\prime \prime} \mathrm{N}$, longitude $14^{\circ} 30^{\prime} 18^{\prime \prime}$ E) was presented to the Small animal clinic (Veterinary Faculty, University of Ljubljana) with frequent sneezing and nose licking of an acute onset. The owner reported that the clinical signs started after the dog was taken for a walk to a nearby meadow field in the city center. Clinical examination of the dog revealed low grade serous bilateral nasal discharge with no other changes in her clinical status. A complete blood count was performed to rule out infectious diseases, which showed no abnormalities. Based on the suspected diagnosis of a nasal foreign body, a rhinoscopy was performed the same day. Mild oedema and erythema of the mucosal surface with several small moving larvae-like structures was noticed in the nasal cavity (Figure 1). More than 30 larvae-like structures were noted further down the nasopharynx. Retrograde irrigation of the nasal cavity with saline removed the larvae-like structures, which were sent to the Parasitology department of the Veterinary Faculty (University of Ljubljana) for identification. While waiting for a parasitological diagnosis, the dog was treated with ivermectin (Ivomec 1\%, Merial) at a dose of $0.03 \mathrm{mg} / \mathrm{kg}$, applied subcutaneously three times at weekly intervals. The owner stated that the clinical signs subsided within the first week of starting treatment and disappeared completely two weeks after the initial diagnosis. The sneezing resolved one day after rhinoscopy and nasal lavage.

The parasitological diagnosis of first larval stage (L1) of Oestrus ovis L (Diptera, Oestridae) was made, based on key morphological features (16) observed under light microscopy. The dorsoventrally flattened L1 was approximately $1.2 \mathrm{~mm}$ long and $0.4 \mathrm{~mm}$ wide. The larval body was divided into 11 segments, with a pair of prominent, dark brown oral hooks on the first segment (Figure 2) and caudal spines on the last segment (Figure 3). 


\section{Discussion}

Nasal bot fly, Oestrus ovis, causes myasis in small ruminants (1), but other casual hosts, such as humans (7) and carnivores $(2-6,8)$ have also been reported. The presence of sheep nasal bot flies in Slovenia was recorded in 1997 with a seroprevalence of $40 \%$ (13). Since then, several cases have been reported in Slovenia, in which third stage larvae were identified in sheep (unpublished data). In this study, we report the first case of $O$. ovis L1 infestation in a dog in Slovenia.

The dog presented in this case, lives in the city of Ljubljana, which has a pre-alpine climate. As discussed by Zanzani et al (6), climate change may have been an important component in the spread of $O$. ovis habitat above $45^{\circ} \mathrm{N}$ latitude. Although there have been sporadic local reports of nasal bot fly infestation in sheep, no study has been done to determine its prevalence since 1997 (13). The 4-year-old dog lived most of its life in an urban environment. According to the owner, the dog had no contact with sheep or areas associated with sheep. However, Ljubljana as a city is still highly accessible to the rural surroundings, where flocks of sheep are present. It is common for dog owners who live in the city to walk their dogs through the livestock pastures and rural areas, especially in the summer. Adult nasal bot flies are very active during the hot summer months $(14,17)$ and explains the infestation of the dog in August. If the infestation would go unnoticed by the owner, the $O$. ovis L1 would remain quiescent during the cold winter months and continued its development the following spring $(14,17)$. This was the case of a dog in the UK, where the dog expelled the mature larva in the spring of 2011, following the presumptive infestation in autumn 2010 (5).

Reportedly the infestation of $O$. ovis in dogs and cats are less likely than in humans (6), where it usually causes ophthalmomyiasis $(7$, 18). To the authors knowledge, no human cases have been documented in Slovenia to date. However, there have been several cases of human ophthalmomyiasis in Italy and two recent cases in Croatia (7). It is suspected that the incidence of ocular myiasis in humans is underreported (7), as is with canine cases of nasal myiasis (6). Nasal myiasis due to $O$. ovis infestation should be considered as a differential diagnosis when an animal is presented with signs of rhinitis, sneezing and nasal discharge $(3,4,6)$. With climate change the prevalence and distribution of $O$. ovis may increase and expand (5) to non-Mediterranean regions. In conclusion, it is important to emphasize the role of reporting disease occurrence in both, animals and humans, and determining the prevalence of sheep nasal bot flies in populations previously believed not to be at risk.

\section{References}

1. Zumpt F. Myiasis in man and animals in the old world: a textbook for physicians, veterinarians and zoologists. London : Butterworths, 1965.

2. Lucientes J, Ferrer-Dufol M, Andres MJ, Peribanez MA, Gracia-Salinas MJ, Castillo JA. Canine myiasis by sheep bot fly (Diptera: Oestridae). J Med Entomol 1997; 34(2): 242-3.

3. Luján L, Vázquez J, Lucientes J, Panero JA, Varea R. Nasal myiasis due to Oestrus ovis infestation in a dog. Vet Rec 1998; 142(11): 282-3.

4. Heath ACG, Johnston C. Nasal myiasis in a dog due to Oestrus ovis (Diptera: Oestridae). N Z Vet J 2001; 49(4): 164.

5. McGarry J, Penrose F, Collins C. Oestrus ovis infestation of a dog in the UK. J Small Anim Pract 2012; 53(3): 192-3.

6. Zanzani SA, Cozzi L, Olivieri E, Gazzonis AL, Manfred MT. Oestrus ovis L. (Diptera: Oestridae) induced nasal myiasis in a dog from Northern Italy. Case Rep Vet Med 2016; 2016: e5205416. doi: $10.1155 / 2016 / 5205416$

7. Pupić-Bakrač A, Pupić-Bakrač J, Škara Kolega M, Beck R. Human opthalmomyiasis caused by Oestrus ovis - first report from Croatia and review on cases from Mediterranean countries. Parasitol Res 2020; 119(3): 783-93.

8. Webb SM, Grillo VL. Nasal myiasis in a cat caused by larvae of the nasal bot fly, Oestrus ovis. Aust Vet J 2010; 88(11): 455-7.

9. Sotiraki S, Hall MJR. A review of comparative aspects of myiasis in goats and sheep in Europe. Small Ruminant Res 2012; 103(1): 75-83.

10. Dorchies P, Bergueaud JP, Tabouret G, Prevot F, Jacquiet P. Prevalence and larval burden of Oestrus ovis (Linné, 1761) in sheep and goat in northern Mediterranean region of France. Vet Parasitol 2000; 88(3/4): 269-73.

11. Scala A, Solinas G, Citterio CV, Kramer H, Genchi C. Sheep oestrosis (Oestrus ovis, Linné 
1761, Diptera, Oestridae) in Sardinia, Italy. Vet Parasitol 2001; 102(1/2): 133-41.

12. Alcaide M, Reina D, Sánchez-López J, Frontera E, Navarrete I. Seroprevalence of Oestrus ovis (Diptera, Oestridae) infestation and associated risk factors in ovine livestock from Southwestern Spain. J Med Entomol 2005; 42(3): 327-31.

13. Brglez J, Polajner V. Oestrosis in sheep. Vet Nov 1997; 23: 393-4.

14. Hall M, Wall R. Myiasis of humans and domestic animals. Adv Parasitol 1995; 35: 257-334.

15. Gomez-Puerta LA, Alroy KA, Ticona DS, Lopez-Urbina MT, Gonzalez AE. A case of nasal myiasis due to Oestrus ovis (Diptera: Oestridae) in a llama (Lama glama). Rev Bras Parasitol Vet 2013; 22(4): 608-10.
16. Colwell DD. Larval morphology. In: Colwell DD, Hall MJ, Sholl PJ, eds. The Oestrid flies: biology, host-parasite relationship, impact and management. Cambridge : CABI Publishing, 2006: 98-122.

17. Cepeda-Palacios R, Angulo Valadez CE, Scholl JP, Ramirez-Orduna R, Jacquiet P, Dorchies P. Ecobiology of the sheep nose bot fly (Oestrus ovis L.): a review. Revue Méd Vét 2011; 162(11): 503-7.

18. D'Assumpcao C, Bugas A, Heidari A, Sofinski S, McPheeters RA. A case and review of ophthalmonyiasis caused by Oestrus ovis in the central valley of California, United States. J Investig Med High Impact Case Rep 2019; 7: e2324709619835852. doi: $10.1177 / 2324709619835852$

\title{
PRVI PRIMER PASJE MIAZE Z OVČJIM NOSNIM ZOLJEM, Oestrus ovis, V SLOVENIJI
}

\author{
A. Vergles Rataj, P. Bandelj, V. Erjavec, D. Pavlin
}

Izvleček: Med rinoskopijo in spiranjem nosne votline, smo pri psu, ki živi v urbanem okolju, ugotovili ličinke prve stopnje (L1) zajedavca Oestru ovis. Lastniki so psa pripeljali na Kliniko za male živali po akutnem izbruhu kihanja in bilateralnega nosnega izcedka. V Evropi so dokumentirani sporadični primeri nosne miaze pri psih zaradi ovčjega nosnega zolja, O. ovis, in skupna prevalenca ovčjega zajedavca je v mediteranskih državah visoka. Zaradi klimatskih sprememb, se habitat nosnih zoljev čedalje bolj širi, za kar je pomembno O. ovis vključiti v seznam diferencialnih diagnoz pri pacientih s kliničnimi znaki rinitisa tudi na področjih, ki mejijo na mediteransko klimo. To je prvi opisan primer infestacije psa z ovčjim nosnim zoljem v Sloveniji.

Ključne besede: Oestrus ovis; ovčji nosnizolj; nosna miaza; pes; podnebne spremembe 